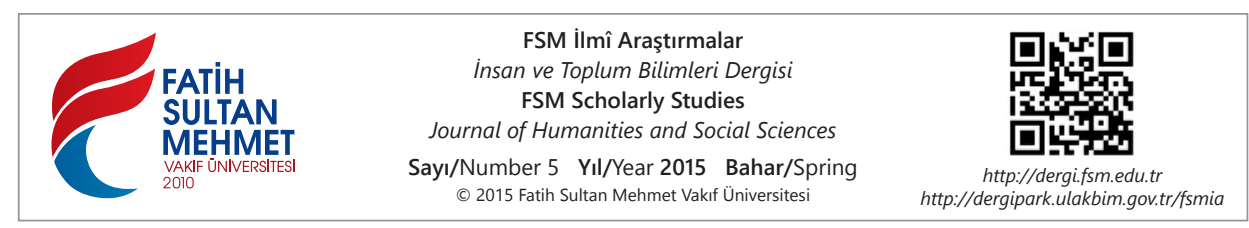

\title{
Osmanlı Hariciyesinde Yaklaşık Kırk Yıl: Mahmud Esad Paşa (1837- 1895) \\ Mahmut Akpınar*
}

\section{Özet}

II. Mahmud döneminin sonlarına doğru sürekli diplomasi anlayışı çerçevesinde Avrupa ile yeniden diplomatik ilişkiler kuran Osmanlı İmparatorluğu'nda görünür en önemli sorun, Müslüman teb'adan sefir düzeyinde istihdam edilecek yetişmiş personelin bulunmayışı idi. Ancak zaman içinde geçte olsa bu sorun aşıldı. Sefirlerin bir bölümü hariciye kalemlerinde yetişmeye başladı. Tanzimat'tan devletin yıkılışına değin yüz otuzu aşkın kişi Osmanlı İmparatorluğu’nu farklı düzeylerde diplomatik temsilci olarak temsil etti. Bunlardan biri de beş farklı başkentte görev yapan Mahmud Esad Paşa idi. Esad Paşa hariciye geleneğine uygun olarak temelden yetişmiş ilk sefir idi. Bu çalışmada esas olarak, Esad Paşa'nın aldığı eğitim, hangi kurumlarda mesleki eğitim alıp tecrübe kazandığı ve bir diplomat adayı haline geldiği, bilahere hariciye birikimini hangi diplomatik merkezlerde nasıl kullandığı üzerinde durulmaktadır.

Anahtar Kelimeler: Osmanlı modernleşmesi, hariciye, diplomasi, sefir.

\section{About Forty Years in the Ottoman Foreign Affairs: Mahmud Esad Pasha (1837-1895)}

\section{Abstract}

Towards the end of the era of Mahmud II within the framework of permanent diplomatic system establishing diplomatic relations with Europa again in the Ottoman Empire appears the most important issue that the lack of the personnels brought up from the Muslim subjects to be employed at the level of ambassador, respectively. However, though over time this problem has been exceeded. By the time some of diplomats was trained by the foreign offices. From Tanzimat to the fall of the state the Ottoman Empire was represented by more then one hundred and thirty diplomatic representatives at different levels. One of those who served in five different capital Mahmud Esad Pasha was. In accordance with the tradition of foreign affairs Esad Pasha was the first ambassador brought up from the ground up. In this study mainly, it is emphasized the education of Esad Pasha, which institutions he took vocational education and won the experience and becoming a candidate of diplomat, afterwards his experinece of the foreign affairs, in which diplomatic centers how he used it.

Keywords: The Ottoman modernization, foreign affairs, diplomacy, ambassador.

* Yrd. Doç. Dr., Cumhuriyet Üniversitesi İletişim Fakültesi Gazetecilik Bölümü, Sivas/Türkiye, makpinar25@hotmail.com 


\section{Giriş}

1699 Karlofça Antlaşması ve sonraki yüzyılda yaşananlar, Osmanlı İmparatorluğu'nun dış politika ve diplomasi algısına tesir etmiştir. Nitekim XVIII. yüzyılın sonlarına doğru III. Selim Londra, Berlin, Viyana ve Paris gibi önemli başkentlere ikamet elçilikleri açarak geçici diplomasiden sürekli diplomasiye geçişi gerçekleştirmiştir. Batıya doğru atılan bu adım, diplomaside uluslararası normların kabul edildiğinin ilk işareti olmuştur. XIX. yüzyıldan itibaren İtalyan liman kentlerinden başlayarak şehbenderler tayin edilmesiyle, III.Selim diplomasiyi uluslararası standartlara göre biçimlendirmeye kararlı olduğunu göstermiştir.

İmparatorluk yönetimi, aşağı yukarı Hariciye Nezareti’nin kurulduğu yıllara kadar diplomaside profesyonel olmayan kişilerle çalışmak zorunda kalmıştır. Bu yıllardan itibaren yavaş yavaş devreye giren Mustafa Reşid Paşa, Âli Paşa ve Fuad Paşa gibi devleta damları vasıtasıyla bu hizmet daha profesyonel bir şekilde yürütülmeye çalışılmıştır. Ancak, imparatorluğun geri kalan ömründe de imparatorluğu temsilen muhtelif ülke merkezlerine farklı meslek gruplarından kişilerin elçi olarak atanmasına devam edilmiştir. Atanan bu elçilerin yaklaşık olarak üçte birinin mesleki altyapıya sahip olduğu görülmektedir. Diplomatik faaliyetler bakımından son yüzyılı oldukça yoğun geçen Osmanlı İmparatorluğu'na meslekten yetişerek hizmet eden elçilerden biri de Esad Paşa'dır. Bu çalışmada bu yönü sebebiyle Esad Paşa ele alınacaktır.

\section{Sürekli Diplomasi Sürecinde Osmanlı Sefirlerine Genel Bir Bakış}

Sürekli diplomasi yolunda ilk adım atılırken her ne kadar III.Selim şehzadeliğinden beri yakın temasta olduğu Fransa'y1 tercih etse de, Fransız İhtilali'nin Osmanlı İmparatorluğu'nda yarattığı tereddüt ve ihtilalden ötürü Avrupa'daki siyasi atmosfer ilk sefirin Paris'e gönderilmesine engel olmuştur. ${ }^{1} \mathrm{Bu}$ dönemde Íngiltere ile olan yakınlık artmış, hatta elçi tayini hususunda İngilizlerin İstanbul elçisi Lord Ainslie ile görüş alışverişinde bulunulmuştur. ${ }^{2}$ Nitekim yapılan görüşmeler neticesinde 1793'te Yusuf Agâh Efendi'nin Londra'ya elçi olarak gönderilmesine karar verilmiştir. ${ }^{3}$ Takriben dört yıl sonra ise Moralı Seyyid Ali Efendi ${ }^{4}$

1 Ercümend Kuran, “1793-1811 Döneminde İlk Osmanlı Mukim Elçilerinin Diplomatik Faaliyetleri”, Çăgdaş Türk Diplomasisi:200 Yillık Süreç-Ankara 15-17 Ekim Kongreye Sunulan Bildiriler, TTK, Ankara 1999, s. 55; İsmail Soysal, Fransız Ihtilali ve Türk-Fransız Diplomasi Münasebetleri (1789-1802), TTK, Ankara 1999, s. 106.

2 M. Alaaddin Yalçınkaya, "Sir Robert Ainslie'nin İstanbul Büyükelçiliği (1776-1794)", Osmanlı Araştırmaları, XXXI (2008), İstanbul, s. 137.

3 BOA., HAT., 12332, 29 Zilhicce 1207/ 7 Ağustos 1793; İ. Sosyal, Fransız İhtilali, s. 106-107; Ercümend Kuran, Avrupa'da Osmanlı İkamet Elçiliklerinin Kuruluşu ve İlk Elçilerin Siyasi Faaliyetleri 1793-1821, TKAE, Ankara 1988, s. 14 Daha detaylı bilgi için bkz. Alaaddin Yalçınkaya, "Yusuf Agah Efendi”, Yaşamları ve Yapıtlarıyla Osmanlılar Ansiklopedisi, II (2008), YKY, İstanbul, s. 680.

4 BOA., HAT., 9801, 20 Rebiülevvel 1211/ 23 Eylül 1796; Ercümend Kuran, "Ali Efendi (Seyyid, Moral1)”, Yaşamları ve Yapıtlarıyla Osmanlılar Ansiklopedisi, I (2008), YKY, İstanbul, s. 207. 
Paris'te, Ali Aziz Efendi ${ }^{5}$ Berlin'de ve İbrahim Afif Efendi XIX. yüzy1lda imparatorluğun Batı'daki diplomasi üslerinden biri haline gelecek olan Viyana'da ikamet elçisi sıfatıyla göreve başlamışlardır. ${ }^{6}$ Sürekli diplomasinin ilk döneminde dört başkente yedi büyükelçi ve on üç kadar da maslahatgüzar tayin edilmiştir. ${ }^{7}$ Bunlara ilaveten XIX. yüzyıldan itibaren İtalyan liman kentlerinden başlayarak Avrupa'daki birkaç ticari kente şehbenderler atanmıştır. ${ }^{8}$

Bu ilk dönemde devlet yönetimi diplomasi alanında bir geleneğe ve tecrübeye sahip olmadığı için gerekli koşulları taşıyan kişi bulmakta zorluk çekmiş, kalyonlar kâtibi, defter kisedarı, emlak memuru, kethüda kâtibi, Tersane anbar emîni ve beylikçi kisedarı gibi görevleri ifa eden kişileri tercih etmiştir. ${ }^{9}$ Ancak o günkü koşullarda bürokrasinin diplomasiye genel bakışı göz önünde bulundurulduğunda bundan çok daha iyisini beklemenin pek mümkün olamayacağını ifade etmek gerekir. Atanan elçilerden, olağan elçilik işlerini görmeleri ve Batı dünyasını yakından tanıyarak, bu yöndeki bilgi ve tecübelerini devlet için kullanabilecek kişiler yetiştirmeleri beklenmiştir. ${ }^{10}$ Dört başkentle başlayan diplomatik faaliyetlerin birinci döneminde imparatorluk idaresi pek istikrarlı bir görüntü çizememiştir. Bütçe imkanlarının yetersizliği, yönetimin yeterli ilgi göstermeyişi, elçilerin yabancı dil bilmemeleri ve deneyimsizlikleri ilk elçilik faaliyetlerinin sekteye uğramasında en önemli etkenler olarak gösterilebilir. ${ }^{11}$ İlk atamalardan sonra elçilikler maslahatgüzarlık seviyesine indirgenmiştir. 1821 Yunan İsyanı

5 BOA., HAT., 10689, 19 Cemaziyelevvel 1211/ 20 Kasım 1796; Ahmed Schmiede, Osmanl ve Prusya Kaynaklarına göre Giritli Ali Aziz Efendi'nin Berlin Sefareti, İstanbul 1990; Hasan Korkut, Osmanlı Elçileri Gözüyle Avrupa, Gökkubbe Yay., İstanbul 2007, s. 43.

6 BOA., C.HR.., 1716, 26 Safer 1212/ 20 Ağustos 1797; Kuran, a.g.e., s. 43- 46; Roderic H. Davison, Vienna As a Major Diplomatic Post in The Nineteenth Century", ed. Andreas Tietze, Habsburgisch-Osmanische Beziehungen/Relations Habsbourg-Ottomanes, Vienna 1985, s. 265.

7 Londra'ya iki, Paris üç, Viyana ve Berlin'e de birer kişi büyükelçi, Londra’ya dört, Viyana'ya dört, Paris'e üç ve Berlin'e iki kişi maslahatgüzar olarak atanmıştır, bkz. Faik Reşit Unat, $O s-$ manlı Sefir ve Sefaretnameleri, TTK, Ankara 1987, s. 237; Kuran, a.g.e., s. 13- 65; Davison, "Vienna", s. 276.

8 Daha ayrıntılı bilgi bkz. BOA., A.DVNS. ŞHBd, I, s. 1-10.

9 Yusuf Agah Efendi Kalyonlar kâtibiyken, Ali Aziz Efendi Belgrad'ta emlak memuruyken, İsmail Ferruh Efnedi, tersane anbar emiriyken elçilik vazifesine tayin edilmişlerdir, bkz. Kuran, a.g.e.., s. 17; M. Orhan Okay, "Aziz Ali Efendi”, Yaşamlarl ve Yapıtlarılla Osmanlılar Ansiklopedisi, I (2008), YKY, İstanbul, s. 277; M. Alaaddin Yalçınkaya, "İsmail Ferruh Efendi'nin Londra Büyükelçiliği ve Siyasi Faaliyetleri”, Pax Ottomana Studies In Memoriam Prof. Dr. Nejat Göyünç, ed. Kemal Çiçek, Yeni Türkiye Yay. Ankara 2001, s. 383.

10 Kuran, a.g.e. s. 11; Hüner Tuncer, Eski ve Yeni Diplomasi, Ümit Yay., Ankara 1995, s. 54-57.

11 III. Selim'in Seyyid Ali Efendi'ye işbilmezliği yüzünden kızgınlığı, bkz. Kuran, a.g.e., s. 31; Muhib Efendi büyük maddi sıkıntılar çekmiştir, bkz. BOA., HAT., 54103, 27 Cemaziyelevvel 1222/ 28 Ağustos 1807; Muhib Efendi gönderdiği yazılara cevap alamadığından şikayet ediyordu, bkz. BOA., HAT., 53571, 27 Zilkade 1222/ 26 Ocak 1808. 
döneminde ise, Rum maslahatgüzarların imparatorluk alayhindeki çalışmaları adeta bardağı taşırmış ve elçilik faaliyetleri askıya alınmıştır.

1830'larda tekrar başlayan diplomatik faaliyetler daha sistematik ve profesyonel şekilde yürütülerek geliştirilmiştir. Osmanlı İmparatorluğu'nu geri kalan ömründe, yüz otuz beş civarında diplomat yirmiyi aşkın siyasi merkezde temsil etmiştir. ${ }^{12} \mathrm{Bu}$ kişilerin on dördü asker kökenli olup, ${ }^{13}$ diğerlerinin çok büyük bir bölümü imparatorluğun sivil bürokrasisi ve diplomasisi içinde yetişmiş ve imparatorluğa hizmet vermiş devlet adamlarıdır. ${ }^{14}$ Devlet adamları sadrazamlık, nazırlık, Şura-yı Devlet üyeliği, müsteşarlık, mutasarrıflık gibi görevleri yürütürken şartlar gereği muhtelif ülke merkezlerine elçi olarak tayin edilmişlerdir. Daha önce de ifade edildiği gibi yüz otuz beş diplomatın yaklaşık üçte birlik kısmı, aşağı yukarı bu mesleğin çarklarından geçmiş, bu alana yönelik bilgi birikimine ve donanıma sahip kişilerdir. ${ }^{15}$ Öte yandan diplomatların dörtte bire yakınının gayrimüslimler, geri kalanının da Müslümanlar arasından seçildiği görülmektedir. ${ }^{16}$

\section{2. (Mahmud) Esad Paşa'nın Aile ve Eğitim Hayatı}

Mahmud Esad Paşa ulemadan İzmirli Bayındırzade Mustafa Hasib Efendi'nin oğludur. Mustafa Hasib Efendi müderrislik vazifesi dışında Trablusgarb'ta eyalet mollalığ yapmıştır. ${ }^{17} 1846$ yılında İstanbul'da vefat etmiştir. Mezarı Selimiye'dedir. Esad Paşa'nın ağabeyi, Emin Muhlis Paşa 1811'de doğmuştur. Divan-1 Hümayun tercümanlığ 1 , Şam, Erzurum ve iki kez de Trabzon valiliği görevlerinde bulunmuştur. ${ }^{18}$ İmparatorluğa vali olarak uzun y1llar hizmet eden Emin Muhlis Paşa 1874 sonbaharında hayata veda etmiştir.

12 Sinan Kuneralp, Son Dönem Osmanlı Erkânı ve Ricali (1839- 1922) Prosopografik Rehber, İsis Press, İstanbul 1999, s. 45- 48.

13 Bunlardan birkaçı; Ahmed Cevad Paşa 1884'te Çetine sefirliğine atandı, bkz. BOA., DH. SAIDd., 2/1006; Abdülkadir Özcan, "Ahmed Cevad Paşa", Yaşamlart ve Yapıtlarıly Osmanlılar Ansiklopedisi, I (2008), YKY, İstanbul, s. 112; Mahmud Muhtar Paşa 1913’te Berlin sefirliği görevine atand, bkz İbrahim Alaeddin Gövsa, Meşhur Adamlar: Hayatlarl ve Eserleri, Sedat Simavi Yay., İstanbul 1949, s. 234-235; Hüseyin Hüsnü Paşa 1889'da Petersburg sefirliğine tayin edildi, bkz BOA. DH.SAIDd., 26/435; Mehmed Zeki Pakalın, Sicill-i Osmanî Zeyli, IX, Yay. haz. Ali Aktan, TTK, Ankara 2008, s. 125.

14 Kuneralp, a.g.e., s. 45-48; Sinan Kuneralp, "Tanzimat Sonras1 Osmanlı Sefirleri”, Çă̆daş Türk Diplomasisi:200 Yıllık Süreç- Ankara 15-17 Ekim Kongreye Sunulan Bildiriler, TTK, Ankara 1999, s. 114.

15 Kuneralp, “Tanzimat Sonrası”, s. 114; Ayrıntılı bilgi için Kuneralp'in kitabına bkz. Kuneralp, a.g.e.

16 Osmanlı diplomatları arasında on iki Rum, beş Ermeni, dört Levanten, üç Romen, üç yabancı ülke vatandaşı olup Osmanlı hizmetine girmiş Avrupal1, iki Hıristiyan Arap ve bir Bulgar olmak üzere toplam otuz diplomat bulunmaktaydı, bkz. Kuneralp, a.g.e., s. 45- 48.

17 Mehmed Süreyya, Sicill-i Osmanî, II, Yay.haz. Nuri Akbayar, 1999, s. 650; BOA., I.DH., 4862, 18 Muharrem 1261/ 27 Ocak 1845

18 Şam valiliğine dair, bkz. BOA., I.DH., 30924, 22 Rebiülahir 1277/ 7 Kasım 1860; İlk Trabzon valiliğine dair, bkz. BOA., İ.DH., 33759, 29 Rebiülevvel 1279/ 24 Eylül 1862; Erzurum valiliğine dair, bkz. BOA., I.DH., 37672, 27 Cemaziyelevvel 1282/ 18 Ekim 1865. 
Mahmud Esad Paşa sürekli diplomasinin ikinci döneminin başladığı ve hariciyenin kurumsallaşma dönemine girdiği bir sırada, 1837 yılında İzmir'de dünyaya gelmiştir. ${ }^{19}$ Eğitim ve meslek edinimi için İstanbul'a getirilen Mahmud Esad reform politikalarının bir neticesi olarak eğitim ve öğretim sistemine yakın zamanda dahil edilmiş olan Beyazıd Rüşdiye'sine devam etmiştir. ${ }^{20}$ Sultan Beyazıd Türbesi dahilinde olan bu mektepte Arapça, Farsça, hesap ve coğrafya gibi dersler almıştır. ${ }^{21}$ On üç yaşındayken klasik dönemin ayakta kalan kurumlarından birisi olan Divan-1 Hümayun Kalemi'ne mülazım olarak girmiştir. ${ }^{22} \mathrm{Bu}$ kaleme girdiğinde kalemin amirliğini Beylikçi Şevket Bey yapmaktayd ${ }_{1 .}{ }^{23}$ Burada yaklaşık dört yıl eğitim aldıktan sonra 1854'te Kırım Harbi sırasında aynı statüde Babıâli Tercüme Odası'na geçmiştir.

Osmanlı bürokrasisinin önemli eğitim birimlerinden biri olan Tercüme Odası'nda bir müddet eğitim gördükten sonra devlet tarafından yüksek öğrenim için Paris'e gönderilmiştir. ${ }^{24}$ Paris'e 1855 yılında on dokuz yaşındayken gittiği belirtilmektedir. ${ }^{25} \mathrm{O}$ günler, Osmanlı İmparatorluğu'nun Rusya'ya karşı Avrupa'nın önemli devletleriyle ittifak yaptığ 1 yani Kırım Harbi’nin yaşandığı günlerdi. Esad Bey'in okuduğu okul bir belgede Paris Mektebi ismiyle anılmaktadır. Esad Bey, bu mektepteki öğrenimini 1858 sonbaharında tamamlamıştır. ${ }^{26}$

\section{Mahmud Esad Paşa'nın Meslek Hayatının İlk Dönemleri}

\subsection{Divan-ı Hümayun Kalemi'nden Tercüme Odası'na}

Mahmud Esad Bey hariciye bünyesinde yer alan Divan-1 Hümayun Kalemi'ne intisab ederek mesleğe ilk adımı 1850'de onüç yaşındayken atmıştır. Muhtemelen bu birime Divan-1 Hümayun mütercimliği görevini yürüten ağabeyi Emin Muhlis Efendi'nin desteğiyle girmiştir. ${ }^{27}$ Onun bürokasiye intisap ettiği dönemde

191253 senesi şehr-i Ramazan'ın 29'nda İzmir'de tevellüd etmiştir, bkz. BOA., DH.SAIDd., $1 / 604$.

20 Bayezid Rüşdiyesi, Davud Paşa Rüşdiye Mektebi'nin ardından açılan mekteplerden biridir, bkz. BOA., I.DH., 9411, 07 Receb 1264/ 9 Haziran 1848; BOA., I.MVL., 3298, 10 Za 1264/ 8 Ekim 1848.

21 Cahit Bilim, Tanzimat Devrinde Türk Eğitiminde Çă̆daşlaşma(1836-1876), Anadolu Üniversitesi Yay., Eskişehir 1984, s. 45; Salname-i Devlet-i Aliyye 1274, s. 130.

22 Mehmed Zeki Pakalın, Sicill-i Osmanî Zeyli, VI, Yay. haz. Özen Tok- Hava Selçuk, TTK, Ankara 2008, s. 7.

23 Salname-i Devlet-i Aliyye 1266, s. 27; Şevket Bey 1846'dan beri bu görevi yürütmekteydi, bkz. BOA., I.HR., 1685, 11 Şevval 1262/ 02 Ekim 1846.

24 BOA., DH.SAIDd., 1/604; The Levand Herald, 16 April 1895.

25 The Levand Herald, 16 April 1895.

26 Paris Mektebi'nde tahsilde bulunan Esad Bey'in Petersburg Maslahatgüzâr1 Haydar Efendi'nin mâiyyetine ta'yînine dâir...., bkz. BOA., I.DH., 8582, 01 Rebiülevvel 1275/ 9 Ekim 1858.

27 Salname-i Devlet-i Aliyye 1266, s. 27; Kuneralp, “Tanzimat Sonras1”, s. 113; BOA., HR.MKT., 12/10, 09 Rebiülevvel 1262/ 07 Mart 1846. 
devlet idaresinde Mustafa Reşid Paşa ve onun yetiştirmeleri olarak görülen Âli ve Fuad Paşa gibi devlet adamlarının etkinliği göze çarpmaktaydı. Hariciyenin başında Âli Paşa bulunmaktaydı. Bürokrasi ve diplomasideki iş yüküne ve yoğunluğa paralel, devletin kurumsal yapısı hızla büyümekte ve bünyesindeki birimlerin sayısı çoğalmaktaydı. Reisülküttaplıktan kalma bir alışkanlıkla Divan-1 Hümayun Kalemi hariciye bünyesindeydi ve merkezi bir yer işgal etmeye devam ediyordu. Bu veya benzeri birimlerde önce Türkçe kitabet, inşa ve yazı türleri öğretilir, ardından memur adayları kendi gelişimlerine ve durumlarına göre başka kalemlere kaydırlırdı. Buradaki yetenekli gençlerin bazıları Tercüme Odası'na alınıyordu. Esad Bey bu kalemlerde dört yıl mülazımlık yaptıktan sonra devrin gözde kalemi Tercüme Odası'na nakledilmiştir.

Refom hareketlerinin iyice ivme kazandığı bir dönemde imparatorluğun bürokratik ortamına Divan-1 Hümayun Kalemi gibi önemli bir kalemden giriş yapan Esad Bey daha sonra ise dış politika ve diplomasinin kalifiye personel ihtiyacını karşılamak üzere teşkil edilen Tercüme Odası'na girmiştir. ${ }^{28}$ İmparatorluğun büyük önem atfettiği bu odaya geçişi, hariciyede başlayıp hariciyede bitecek olan kariyeri için de isabetli bir adım olmuştur. O yıllarda kariyer bakımından odanın iyi bir şöhreti vardı. Zira Âli Paşa'dan ötürü “Tercüme Odası'ndan geçmek fakir bakkalın oğlunu sadrazam yapar" sözü imparatorlukta yer etmişti. ${ }^{29}$ Önceleri Tercüme Odası'nda Fransızca derslerinin yanı sıra tarih-i umûmî ve fenn-i hesap gibi dersler verilmekteydi. ${ }^{30}$ Fakat zamanla bu derslerin terk edildiği söylenmektedir. ${ }^{31}$ Ancak sonraki yıllarda ders adedinin arttığı, Fransız hukuku ve milletler hukuku gibi derslerin de ilave edildiği görülmektedir. Esad Bey'in odada çalıştığ sıralarda bu işin uzmanı olarak Yanko Aristraki, Sahak Abro ve Redhouse gibi önemli kişiler farklı statülerde görev yapmaktayd $1 .^{32}$ Esad Bey 1854 yılında çırak olarak girdiği bu birimde bir süre sonra 180 kuruş maaşla memur kadrosuna geçirilmiştir. ${ }^{33}$ Kırım Harbi'nin yaşandığ o yıllarda, artan işlerin de etkisiyle Osmanlı bürokrasisinde yavaş yavaş hariciye kalemi öne çıkmıştı. ${ }^{34}$ Bir yandan da odaya

28 Pakalın, Sicill-i Osmanî Zeyli, VI, s. 7.

29 Cahit Bilim, “ BabıâliTercüme Odası”, OTAM, I (1990), Ankara, s. 40; George Sardou ile on iki ay çalışan Âli Paşa Fransızcayı nispeten öğrendi, bkz. Yılmaz Öztuna, Tanzimat Paşaları Âli ve Fuâd Paşalar, Ötüken Yay., İstanbul 2006, s. 27.

30 Osman Nuri Ergin, Türk Maarif Tarihi, Eser Neşriyat, İstanbul 1977, s. 318.

31 Ali Aky1ldız, Tanzimat Dönemi Osmanlı Merkez Teşkilatında Reform (1836- 1856), Eren Yay., İstanbul 1993, s. 77.

32 Aristarki Bağdat vilayet tercümanlığ görevini yürütürken vefat eden Mösyö Sarafin'in yerine bu vazifeye atanmıştır, bkz. BOA., I.HR., 4180, 07 Cemaziyelahir 1268/ 29 Mart 1852; 1852 'de İstanbul'a geldi ve bir süre sonra Tercüme Odası'nda çalışmaya başladı, bkz. Aykan Candemir- Vağarşağ Seropyan, "Abroyan Sahak", Yaşamları ve Yapıtlarıyla Osmanlılar Ansiklopedisi, I (2008), YKY, İstanbul, s. 78.

33 BOA., DH.SAIDd., 1/ 604; Pakalın, Sicill-i Osmanî Zeyli, VI, s. 7.

34 Abdullah Saydam, "Tanzimat Devri Reformları", Türkler, XII (2002), Yeni Türkiye Yay. Ankara, s. 788; A. Akyıldız, Tanzimat Dönemi., s. 77. 
alınan personel sayısı her geçen artmaktaydı. Bu sebeple de 1856'da dönemin Divan-1 Hümayun Tercümanı Mehmed Kabuli Efendi’nin layihasıyla odada düzenlemeye gidirilerek dersler başta olmak üzere bir dizi yenilik yapılmıştır. ${ }^{35}$

\subsection{Paris’te Yüksek Öğrenim ve Petersburg Sefareti Başkatipliği}

Yukarıda da belirtildiği üzere Tercüme Odası'ndan ayrılarak yüksek öğrenim için Paris'e giden Esad Bey üç yıllık öğrenimin ardından 1858 yılının sonlarına doğru 3000 kuruş (150 ruble) maaşla Petersburg Sefareti'ne tayin edildi. Böylece Esad Bey'in kalfalık süreci başlamış oldu. İbrahim Haydar Efendi'nin maslahatgüzar tayin edildiği dönemde Arif Efendi'nin yerine başkâtipliğe getirilen Esad Bey bir yıla yakın bir müddet sefarette yazı işlerini üstlendi. ${ }^{36}$ Orta elçilik seviyesinde olan bu diplomatik birimde elçi dışında iki kâtip, iki yüzbaşı ve bir tercüman görev yapmaktayd $1 .{ }^{37}$ İmparatorluğun Avrupa'daki diplomatik merkezleriyle kıyaslandığında, bu sefaretin, epey bir süre sonra hizmete açıldığı görülmektedir. Zira devlet uzun yıllar Rusya ile olan münasebetlerde tarihsel geçmişin de etkisiyle sürekli diplomasiden kaçınmış ve bu hususta da hiç istekli görünmemiştir. Esad Bey'in görev yaptığı dönemde, Avrupa'yla uyum çerçevesinde 1856 Paris Kongresi ile Avrupa Hukuk Sistemi'ne dahil edilmiş olan Osmanlı İmparatorluğu'nun, Kırım Harbi ile ciddi şekilde hırpalanmış ve tecrit edilmiş Rusya ile yeni bir diplomatik ilişki sürecine girdiği görülmektedir. Elçiliğin yazı işıerini başarılı bir şekilde yürüten Esad Bey rahatsızlığı münasebetiyle tebdil-i hava için Babıâli'den izin talep etmiştir. İzin verilmiş, ancak Haydar Bey'in görevinden ayrılmasıyla sefarettte oluşan boşluktan ötürü yeni sefir atanana kadar Esad Bey'in görevine devam etmesi istenmiştir ${ }^{38} .1859$ yılı eylülünde Mehmed Derviş Paşa'nın sefir tayin edilmesiyle Esad Bey'e beklediği izin çıkmış ve kendisine İstanbul'a geliş için iki maaş (300 ruble) harcırah verilmiştir. ${ }^{39}$

Esad Bey, sağlık sorunları nedeniyle bu memuriyete geri dönmemiş, tedavi ve istirahatın ardından eski çalıştığı birimde yani Tercüme Odası'nda 750 kuruş maaş ile tekrar çalışmaya başlamıştır. ${ }^{40} \mathrm{Bu}$ tayinle Tercüme Odası halifeleri

35 BOA., I.HR.., 6900, 23 Z 1272/ 25 Ağustos 1856; Akyıldız, a.g.e., s. 77

36 BOA., HR.MKT., 234/69, 27 Ş 1274/ 12 Nisan 1858; BOA., HR.MKT., 259/95, 01 Rebiülevvel 1275/09 Ekim 1858.

37 Salname-i Devlet-i Aliyye 1274, s. 125.

38 BOA., HR.MKT., 302/14, 25 Muharrem 1276/24 Ağustos 1859; BOA., HR.MKT., 315/89, 02 Cemaziyelevvel 1276/ 27 Kasim 1859.

39 BOA., HR.MKT., 302/ 14.

40 BOA., DH.SAIDd., 1/ 604; Pakalın, Sicill-i Osmanî Zeyli, VI, s. 7; BOA., I.HR., 9741, 06 Muharrem 1277/ 25 Temmuz 1860; Petersburg Sefareti bilhassa iklim koşulları nedeniyle sonrasında da sefirlerin pek gitmek veya uzun süre kalmak istemediği bir diplomatik merkez olacaktır. 
arasına dahil edilen Esad Bey'e 1860 yılının ilk aylarında üçüncü rütbe tevcih edilirken maaşı da 930 kuruşa yükseltilmiştir. ${ }^{41} \mathrm{Bu}$ vazifesi sırasında İstanbul'a gelen Fransa'nın eski kralı Louis Philippe'nin torununa mihmandarlık ederek, İstanbul'da kaldığı süre içinde onlarla yakından ilgilenmiştir. Bu görevinden ötürü Kont Dupari memnuniyetinin bir ifadesi olarak kendisine altın bir kutu hediye etmiştir. ${ }^{42}$ Daha sonra rütbesi ikinci dereceye yükseltilen Esad Bey’e beşinci rütbeden Mecidi nişanı verilmiştir. ${ }^{43}$

\subsection{Paris Sefareti’ndeki Görevleri ve Tercüme Odası'na Geri Dönüş}

Esad Bey, 1862 y1lı başlarında 2000 kuruş maaşla Paris Sefareti ikinci kâtipliğine tayin edilmiştir. ${ }^{44}$ Esad Bey'in Paris'te göreve başlamasından bir müddet sonra sefir değişikliği olmuş Tanzimat'ın mimarlarından Mustafa Reşid Paşa'nın oğlu olan Mehmed Cemil Paşa, bu göreve atanmıştır. ${ }^{45}$ Esad Bey öğrencilik yıllarından aşina olduğu bu kentte iki farklı görevle bir müddet kalacaktır. İlkin ikinci kâtiplik vazifesiyle sefarette yaklaşık altı yıl çalışan Esad Bey, bu vazifenin sonunda mütemayiz rütbesiyle ve 3000 kuruş maaşla başkâtipliğe terfi ettirilmiştir. ${ }^{46}$ Ayrıca kendisine dördüncü rütbeden Mecidi nişanı verilmiştir. ${ }^{47}$ Sefarette üç kâtip, bir başkonsolos, bir ateşe, bir ateşemiliter ve bir de kançılar bulunmaktaydı. Osmanlı tarihinde bir ilk olarak mühim bir yer tutan Sultan Abdülaziz'in kırk yedi günlük Avrupa seyaheti de bu döneme rastlamaktadır.

Esad Bey, 1869 sonbaharında 3810 kuruş maaşla emekliye ayrılan Halis Efendi'nin yerine Mütercim-i sani atanmış ve bu vazifeyle tekrar payitahta geri dönmüştür. ${ }^{48} \mathrm{O}$ dönemde Âli Paşa sadrazamlığın yanı sıra hariciye nazırlığı görevini de yürütmekteydi. Esad Bey, yetişmesinde pay sahibi olan Tercüme Odası'nda takriben iki yıl, ikinci adam olarak Mütercim-i evvel Ali Fuad Bey ile birlikte görev yapmıştır. ${ }^{49}$

41 BOA., I.HR., 10588, 22 Cemaziyelahir 1278/ 25 Aralık 1861.

42 BOA., I.HR., 9741.

43 BOA., DH.SAIDd., 1/604; The Levand Herald, 16 April 1895.

44 BOA., I.HR.., 14247, 19 Receb 1286/ 25 Ekim 1869; BOA., I.HR., 14190, 23 Cemaziyelevvel 1286/ 31 Ağustos 1869.

45 BOA., I.HR., 10854, 29 Zilkade 1278/ 28 Mays1 1862.

46 Salname-i Devlet-i Aliyye 1286, s. 147.

47 The Levant Herald, 16 April 1895.

48 BOA., I.HR.., 14247; Sicilindeki tayin tarihi belgelerle uyuşmuyor, 1285 senesinin evasıtında tayin olduğu belirtiliyor, bkz. BOA., DH.SAIDd., 1/604; BOA., I.HR., 14190, 23 Cemaziyelevvel 1286/ 31 Ağustos 1869.

49 Salname-i Devlet-i Aliyye 1286, s. 53. 


\section{Diplomat Olarak Esad Bey'in İlk Görevleri}

\subsection{Peşte Başşebenderliği ve Atina Sefirliği}

1856 Paris Konferansı sonrası başlayan diplomasi atağının bir uzantısı olarak 1868 sonbaharında teşkil edilen Peşte başşehbenderliğine tayini ile Esad Bey, mesleki kariyerine konsolosluk vazifesini de eklemiştir. ${ }^{50}$ Esad Bey, bu atama ile tekrar Avrupa'dadır. Sadowa (1866) yenilgisiyle Avusturya'daki siyasi ve idari yapı artık değişmiş, dualist bir yapı ortaya çıkmıştır. Esad Bey Peşte'ye 1870 sonbaharında gelmiştir. Kendisine 7500 kuruş maaş bağlanmıştır. ${ }^{51}$ Buradaki vazifesi, bu şehre gelip giden imparatorluk tebaasının genel ve hususi işleriyle meşgul olmaktı. ${ }^{52} \mathrm{Bu}$ tayinle Esad Bey kalfalık döneminin artık sonuna gelmiştir. Mesleğinde belirli bir tecrübe ve olgunluğa ulaşan Esad Bey’i artık daha mühim görevler beklemektedir.

İki yılı aşkın bir süre Peşte'de başşehbenderlik görevini ifa eden Esad Bey 1872 sonbaharında 20000 kuruş maaşla Atina Ortaelçiliğine atanmıştır. Bu tayin sırasında rütbesi birinci dereceye yükseltilirken aynı zamanda kendisine üçüncü rütbeden Osmani nişanı verilmiştir. ${ }^{53}$ Bu göreve dönemin önemli devlet adamlar11 arasında gösterilen Halil Şerif Paşa'nın hariciye nazırlığı sırasında atanmıştır. Atina sefirliği, Esad Bey'in ilk sefirlik vazifesi olması münasebetiyle kariyeri bakımından önemli bir merhaledir. Esad Bey Atina'ya Yanko Fotyadis'in dokuz yılı aşan sefirliğinin ardından gelmiştir. 1866-1869 Girit İsyanı sırasında yaşanan siyasi gerilimin ardından 1870'lerde Osmanlı-Yunan ilişkilerinde tansiyonun nispeten düşük olduğu ve ilişkilerin rutin bir şekilde devam ettiği söylenebilir. Bu dönemde bilhassa Girit İsyanı'nın doğurduğu birtakım problemler, sınır ihlalleri, eşkiyalık hareketleri ve H. Schliemann'ın tarihi eser kaçakçılığı, iki ülke arasındaki gündemi meşgul etmiştir. ${ }^{54}$ Öte yandan 1874 yılı başlarında konumu göz önünde bulundurularak rütbesi tekrar yükseltilerek Esad Bey’e ikinci rütbe-

50 BOA., I.HR., 13797, 14 Cemaziyelahir 1285/ 2 Ekim 1868; Avusturya'nın Avusturya-Macaristan İmparatroluğu'na dönüşmesinin ardından Macarlarla iyi ilişkilerini sürdürmek isteyen Osmanlı yönetimi 1868'de Miralay Ali Nizami Bey'i atayarak Peşte Başşehbenderliği'ni açmıştır, bkz. Salname-i Devlet-i Aliyye 1286, s. 149; BOA., .C.HR., 7511; Fahir Armaoğlu, 19. Yüzyll Siyasi Tarihi (1789-1914), TTK, Ankara 1997, s. 318.

51 BOA., A.DVNS. ŞHBd, 1, s. 120; BOA., C.HR., 7511, 28 Cemaziyelahir 1287/ 25 Eylül 1870; Sicilinde bu tayini ile ilgili bilgide de hata var, zira 1286 senesinin evailinde tayin olduğu ifade ediliyor, bkz. BOA., DH.SAIDd., 1/604.

52 BOA., C.HR., 7511; BOA., A.DVNS. ŞHBd., 1, s. 120.

53 Esad Bey’e üçüncü rütbeden Mecidi nişanı verilmesi düşünülmüş, ancak işgal ettiği mevki sebebiyle yeterli olmayacağ gerekçe gösterilerek, verilecek nişan değiştirilmiştir, bkz. BOA., I.HR., 15355, 10 Ramazan 1289/ 11 Kasım 1872; Sicilinde üçüncü rütbeden Mecidi nişanı verildiği yazar, bkz. BOA. DH.SAIDd., 1/604; The Levant Herald, 16 April 1895.

54 BOA., I.MTZ.GR., 432, 04 Ramazan 1289/ 05 Kasim 1872; BOA., A.MKT. MHM., 454/55, 19 Rebiülevvel 1290, 17 Mayıs 1873; BOA., MF.MKT., 97/18, 23 Rebiülahir 1291/ 09 Haziran 1874. 
den Mecidi nişanı verilmiştir. ${ }^{55}$

Esad Bey'in Yunan yönetimi ile iyi ilişkiler içinde olduğu ve hüsn-i kabul gördüğü anlaşılmaktadır. ${ }^{56}$ Nitekim iyi niyetin bir emaresi olarak ilk önce padişah tarafindan Yunan kralına bir nişan gönderilmiş ve akabinde Yunan kralı, sefaret heyetini verdiği davetle iyi şekilde ağırlayıp, Esad Bey’i birinci rütbeden Sover nişanı ile taltif etmiştir ${ }^{57}$. Kronik hastalığı münasebetiyle yüksek sıcaklıktan olumsuz etkilenen Esad Bey, hekimlerin bilgisi ve tavsiyesi doğrultusunda 1873 y1lı Temmuz ve Ağustos ayları için izin alarak İstanbul'a gelmiştir. ${ }^{58}$ Hastalığına rağmen bir süre daha Atina sefirliği görevini devam ettiren Esad Bey 1874 y1lı sonlarında bu görevinden ayrılmak zorunda kalmıştır. ${ }^{59}$ Her ne kadar hastalığ bu vazifede çok daha uzun bir müddet kalmasına müsaade etmese de, Esad Bey mesleki olarak artık ustalık elbisesini giymiş ve daha üst seviye görevleri zorlayacağının sinyallerini vermiştir. Atina'daki memuriyetin ardından hastalığının tedavisiyle uğraşnan Esad Bey, bir buçuk yılı boşta geçirmiş ve herhangi bir görev almamıştır.

\subsection{Roma ve Viyana Sefirlikleri}

Esad Bey, Sultan Abdülaziz'in öldürülmesi üzerine V. Murad'in tahta çıkarıldığ 1876 yazında 30000 kuruş maaşla Roma ortaelçiliğine atanmıştır. ${ }^{60}$ Hariciye müsteşarlığı görevine ikinci defa tayin edilen Karatodori Efendi'nin yerine atanan Esad Bey İtalya'ya gönderilen ilk müslüman sefirdir. ${ }^{61} \mathrm{O}$ dönemde, Osmanlı

55 BOA., I.HR., 15670/1, 29 Zilhicce 1290/ 17 Şubat 1874; The Levant Herald, 16 April 1895; BOA. DH. SAIDd., 1/604.

56 BOA., I.MTZ (01), 499, 24 Zilkade 1290/ 13 Ocak 1874.

57 Haşmetlü Yunan kralı hazretleri tarafından kendüsüne Sover nişanı'nın grand kordonu i'tâ' olunmuş olduğuna dâir Atina sefiri saâdetlü Esad Bey...., bkz BOA. I.HR., 21531, 23 Zilkade 1290/ 12 Ocak 1874; Esad Bey’e verilen nişan, Osmanlı padişahının Yunan kralına gönderdiği murassa' Nişân-ı âli Osmânî 'nin takdimden bir müddet sonra verilmiştir, bkz. BOA., İ.HR., 15651, 22 Zilkade 1290/ 12 Ocak 1874 ; BOA., I.MTZ (01), 499. ; 'Redamör' "Suver” 1 Haziran sene 1833 'de Kral I. Onon tarafından ihdas ve 1863 Ağustosu'nda resmi değişiklik yapılmıştır., bkz. Sâlnâme-i Nezâret-i Hâriciye, II, Yay. haz Ahmet Nezih Galitekin, İşaret Yay., İstanbul 2003, s. 254.

58 BOA., I.HR., 15515, 15 Rebiülahir 1290/ 12 Haziran 1873.

59 BOA., I.HR., 15778, 13 Cemaziyelevvel 1293/ 28 Haziran 1874; BOA., I.HR., 15869, 19 Ramazan 1291/ 30 Ekim 1874; BOA., HR.TO., 311/13, 09 Şubat 1875.

60 BOA., I.HR., 16300, 05 Cemaziyelahir 1293; BOA., I.HR., 16303, 05 Cemaziyelahir 1293/ 28 Haziran 1876.

61 Daha önce gayrimüslimler arasından 1855'te Yanko Musurus ve 1857'de Rüstem Bey Torino maslahatgüzarlığı, 1857'de S. Spitzer Napoli mashalatgüzarlığı, 1870’te Y. Fotyadi önce Floransa sonra Roma sefirliği, 1872 'de S. Hamamciyan ve 1874 'te A. Karatodori Roma sefirliği görevinde bulunmuşlardır, bkz. BOA., A.DVN.MHM., 15/47, 1272; BOA., A.AMD., 77/22, 1273; BOA., İ.HR., 15324, 19 Şaban 1289/ 22 Ekim 1872; BOA., I.HR., 15675, 9 Muharrem 1291/ 26 Şubat 1874; Kuneralp, Osmanlı Son Dönem, s. 46- 48. 
İmparatorluğu Rusya'nın Panslavist emellerle Balkanlar'da neden olduğu kar1ş1kl1klar münasebetiyle zor günler geçirmekteydi. Öte yandan Esad Bey Roma'da ikinci ayını tamamlarken Payitaht'ta iktidar değişmiş ve II. Abdülhamid tahta çıkmıştır. Esad Bey sefirliği sırasında daha ziyade Balkanlar' da yaşanan gelişmelerin İtalya' daki yansımalarını izleyerek, bunlara dair bilgileri Babıli'ye aktarmıştır. ${ }^{62}$ Esad Bey, Avrupa'nın medeniyet olarak oldukça eski fakat devlet olarak bu genç ülkesinde bir yıl kadar hizmet ettikten sonra hastalığı nedeniyle yine izin talebinde bulunmuştur. ${ }^{63}$ Tedavinin ardından 1877 sonbaharında Viyana'ya tayin edilmiştir. 45000 kuruş maaşla Viyana sefirliğine atanmış ve rütbesi bâlâ sınıfına yükseltilmiş kendisine birinci rütbeden Mecidi nişanı verilmiştir. ${ }^{64}$

Doksan Üç Harbi'nin devam ettiği o günlerde, Osmanlı İmparatorluğu'nun zayıflığını da göz önünde bulunduran Avusturya, Rusya'ya karşı bölgede denge oluşturmak adına Bosna Hersek'i işgal etmek istediği için Osmanlı İmparatorluğu'ndan uzaklaşmışt1. ${ }^{65}$ Savaş sonrası dönemde Bosna- Hersek meselesi, iki ülke arasında gerginliğe yol açmış, konunun diplomatik yollarla çözümü yaklaşık olarak on ay sürmüştür. Viyana Sefiri Esad Bey harbin neden olduğu Bosna problemi ile diğer sorun ve gelişmeleri diplomatik yazışmalar ve görüşmeler vasıtasıyla takip etmiştir. ${ }^{66}$ Bosna-Hersek sorunun çözümü için görevlendirilen Karatodori Paşa'ya da yardımcı olmaya çalışmıştır. Bosna-Hersek ile ilgili diplomatik çözüm arayışları devam ederken Babıâli'de kabine değişikliği olmuş ve 1878 yılı sonlarında Hayreddin Paşa hükümeti kurulduktan sonra Esad Bey 14000 kuruş maaşla Hariciye müsteşarlığına atanmıştır. ${ }^{67}$ Her ne kadar sicilinde, bu göreve yıl sonunda atandığ 1 ifade edilse de belgelerden 1879 yılı Şubat sonu veya Mart başında atandığ 1 anlaşılmaktadır. ${ }^{68} 1879$ baharında diplomatik usüller gereği Avusturya Devleti Esad Bey’e birinci rütbeden Leopold nişanı vermiştir. ${ }^{69}$

62 BOA., I.DH., 61639, 13 Ramazan 1294/ 21 Eylül 1877.

63 Tedavi için Aspa? kaplıcalarına gitmeyi isteyen Esad Bey iki ay izin istemiştir, bkz. BOA., I.HR., 16629, 24 Cemaziyelahir 1294/ 6 Temmuz 1877.

64 BOA., I.HR., 16687, 15 Ramazan 1294/ 23 Eylül 1877.

65 Teyfur Erdoğdu, “1856- Paris Kongresi-1878 Berlin Kongresi Arasında Osmanlı D1ş Politikası”, Çăgdaş Türk Diplomasisi:200 Yıllık Süreç- Ankara 15-17 Ekim Kongreye Sunulan Bildiriler, TTK, Ankara 1999, s. 172.

66 BOA., HR.SYS., 176/40, 23 Ocak 1878.

67 BOA., DH.SAIDd., 1/604.

68 Esad Bey, atamdan dolayı hükümet yetkililerine teşekkürlerini bildiren bir telgraf gönderiyor, bkz. BOA., HR.TO., 131/85, 03.03.1879; BOA., Y.A.HUS., 160/62, 17 Rebiülevvel 1296/ 11 Mart 1879.

69 Haşmetlü Avusturya İmparatoru hazretleri tarafından Hariciye müsteşârı atûfetlü Esad Beyefendi hazretlerine Leopold nişanı 'nın grand kordonu i'tâ' ve sened-i resmisi irsâl..., bkz. BOA., I.HR., 17157, 26 Cemaziyelevvel 1296/ 18 May1s 1879; Bu nişan, 1808 y1lında Avusturya İmparatoru I. Fransuva tarafindan ihdas olunmuştur, bkz. Sâlnâme-i Nezâret-i Hâriciye, II, s. 254. 


\section{Paris Sefirliği}

Arşiv belgesinde "Esad Bey'in politika işlerine olan hakimiyeti ve dirayeti sebebiyle boşta olan müsteşarlık makamına atandığ" 1 ifade edilmektedir. ${ }^{70}$ Kabinede ikinci adam pozisyonunda olan hariciye nazırının yardımcılığına getirilen Esad Bey bürokratik kariyerinin zirvesine çıkmıştır. Atamadan oldukça memnun olan Esad Bey Babıâli'ye bir teşekkür telgrafı göndermiştir. ${ }^{71}$ İlk gayrimüslim Hariciye Nazırı Aleksandır Karatodori Paşa ile kısa bir süre de olsa birlikte çalışmıştır.

Aralık 1878 'de kurulan Tunuslu Hayreddin Paşa kabinesi, padişahla yaşanan sorunlar nedeniyle bir müddet sonra kendi içide sıkıntlar yaşamaya başlamıştır. Tunuslu Hayreddin Paşa hükümetten çekilirken ona destek olan Hariciye Nazırı Karatodori Paşa ardından Esad Bey de görevinden alınmıştır. ${ }^{72}$ Bir süre boşta kalan Esad Bey bu esnada mazuliyet maaşı almıştır. Nisan 1880'de 36000 kuruş maaşla Paris sefirliğine atanmıştır. ${ }^{73}$ Ancak Hariciye Nazırı Sava Paşa menfaatler gereği buna itiraz ederek, Paris’teki temsilcinin büyükelçi olarak değil, beyanlarının devlet nezdinde bağlayıcılığı olmayan maslahatgüzar düzeyinde atanmasının daha isabetli olacağını belirtmiştir. Zira Yunanistan ile Osmanlı İmparatorluğu arasında yaşanan sınır meselesinde Fransa'nın Yunanlılar lehinde bir tavır takınıyor olmaS1 atanacak temsilcinin konumunu önemli kılmaktaydı. Nazırın itirazından dolayı tayin birkaç ay gecikse de atamada bir değişiklik olmadı ve Esad Bey 1880 sonbaharında büyükelçi olarak Paris'te hizmete başladi. ${ }^{74}$

Esad Bey, Paris'e takriben otuz ylllık mesleki tecrübe ve olgunlukla gitmiştir. Nitekim 1881 yılı başlarında birinci rütbeden Osmani nişanı ile vezir yapılmış ve paşa ünvanı verilmiştir. ${ }^{75}$ Esad Paşa, sefaretin rutin işleri dışında yaşanan gelişmeleri de yakından takip ederek Paris gibi önemli bir başkentte uzun sayılabilecek bir süre görev yapmıştır. Esad Paşa sefirliğinin ilk yılında İspanya’ya bir seyahat gerçekleştirmiştir. Paris sefirleri, 1860'ta tasarruf gerekçesiyle kapatıldığından beri Madrid sefirliği içinde yetkilendirilmişlerdi. ${ }^{76}$ Haliyle Esad Paşa da akreditasyon gereği bu

70 Açıkta bulunan Hâriciyye müsteşârlığına münâsib birinin ta'yini lâzım gelmiş ve Viyana Sefiri sâbık atûfetlü Esad Bey Efendi hazretleri umûr-1 politikaya vâkıf ve dirâyetiyle muttasıf tebrîkâtta bulunmuş olmağla zikr olunan müsteşârlığa ..., bkz. BOA., I.HR., 17084, 9 Rebiülevvel 1296/ 3 Mart 1879.

71 BOA., HR.TO., 131/85; Esad Paşa'ya 100 lira tenzille 350 lira harcırah verilmiştir, bkz.BOA., I.HR., 17150, 18 Cemaziyelevvel 1296/ 10 May1s 1879

72 Sicilde 1878 yılı sonlarında göreve geldiği söylense de, belgelerde bunun 1879 bahar döneminde gerçekleştiği görülüyor, bkz. BOA., DH.SAİDd., 1/640; BOA., I.HR., 17084.

73 BOA.I.HR., 21549, 22 Rebiülahir 1297/ 3 Nisan 1880.

74 BOA., I.HR.., 17479, 03 Șevval 1297/ 8 Eylül 1880.

75 Paris sefiri devletlü Esad Paşa hazretlerine tevcih ve ihsân buyrulan rütbe-i resmiye-i vezâretin menşûr-1 âlîsi...,bkz. BOA., İ.DH., 66266, 04 Safer 1298/ 6 Ocak 1881; The Levant Herald, 12 January 1881.

76 Sinan Kuneralp, İspanya'da Osmanlı Temsilciliği ve Osmanl1-İspanyol Müsabetleri (18571922), Türk Kültürü Araştırmaları Dergisi, X-XIV/ 1-2 (1973-1975), Ankara, s. 165. 
vazifeyi üstlenmişti. ${ }^{77} 1881$ yılı sonbaharında hükümetin talebiyle Esad Paşa, İspanya kralını ziyaret edip, nişan vermek ve elçiliğin yeniden hizmete sokulması için Madrid'e gitmiştir. ${ }^{78}$ Akdeniz'deki güç dengesi düşünülerek atılan bu adımla, II. Abdülhamid'in ilişkileri canlandırmak istediği görülmektedir. Bu diplomatik girişimin, çıkarları bakımından Osmanlı İmparatorluğu ile işbirliğini arzulayan İspanyolları da memnun ettiği söylenebilir. Buradaki vazifesinden ötürü İspanya Devleti Esad Paşa'ya Şarl Truva nişanı verdi. ${ }^{79}$ Bu ziyaretin akabinde Hüseyin H. Sermed Efendi takriben yirmi bir yıl sonra Madrid sefiri olarak atanmış oldu. ${ }^{80}$

Esad Paşa'nın sefirliği sırasında yaşanan hadiselerden biri de, 1878'de İstanbul'dan kaçıp Paris'e gelen Odyan Efendi. ${ }^{81}$ Odyan Efendi hakkında dış kaynaklı çeşitli iddialar gündeme gelmiştir. Tutuklanıp sürgün edilen Midhat Paşa ile birlikte hareket ettiği düşünülmüştür. Zira Odyan Efendi'nin meşruti sistemin devam ettirmesinde büyük ülkelerin desteğinin sağlanabilmesi için Midhat Paşa tarafından Paris ve Londra'ya gönderdiği söylenmiştir ${ }^{82}$. Ayrıca Patrikhane yardımıyla kendi cemaati lehinde kamuoyu oluşturma adına girişimlerde bulunduğu iddia edilmiştir. ${ }^{83}$ Paris'e tedavi olmak bahanesiyle üç aylığına giden Odyan Efendi, bir daha ülkeye dönmemiştir. ${ }^{84}$ Gelen

77 Bundan akdem Paris Sefâreti seniyyesine ta'yin olunan zevât İspanya Devleti nezdinde dahi sefir olduklarından zevâtı müşârün-ileyhden bir ikisi taraf-1 eşref hazret-1 tac-dârinden tasdîr buyrulan nâme-i hümâyûnları İspanyol kralı hazretlerine i'tâ etmiş bir müddet sonra bu usûl terk olunmuş olduğundan Paris sefiri ... Esad Paşa hazretlerinin dahi emsâl-i misillü devlet-i müşârün-ileyhâ nezdine sefir ta'yiniyle bir kıt'a nâme-i hümâyûn 1sdarını İspanya sefiri..., bkz BOA., I.DH., 66400, 19 Rebiülevvel 1298/ 19 Şubat 1881.

78 BOA., I.HR., 17690, 19 Şevval 1298/ 14 Eylül 1881; 28 Zilkade 1298/ 22 Ekim 1881; Kuneralp, “İspanya'da Osmanlı", s. 165.

79 BOA., DH.SAIDd., 1/640; 19 Eylül 1771'de Kral III. Şarl tarafından ihdas olunmuştur, bkz. Sâlnâme-i Nezâret-i Hâriciye, I, s. 388.

80 Madrid'te ilk olarak E. De Kerkhove maslahatgüzar tayin edilmiş ve tasarruf düşüncesiyle 1860 yılında sefaretin kapatılmasına karar verilmiştir, bkz. BOA., I.HR., 7768, 09 Safer 1274/ 29 Eylül 1857; Kuneralp, “İspanya'da Osmanlı”, s. 165.; BOA., I.HR., 17708, 01 Zilkade 1298/ 25 Eylül 1881.

81 1834'te İstanbul'da doğan Odyan Efendi, 1854'te Osmanlı bürokrasisine dahil olmuştur. 1871 'de Ticaret Nezareti müsteşarlığı ve 1875 'te Şûrä-yı Devlet azalığı gibi önemli mevkilerde bulunmuştur, bkz. Silvart Kayar-Malhasyan, "Krikor Odyan”, Yaşamları ve Yapıtlartyla Osmanlılar Ansiklopedisi, II, YKY, İstanbul 2008, s. 379

82 Saro Dadyan, Osmanlı'da Ermeni Aristokrasisi, Everest Yayınlarl, İstanbul 2011, s. 274

83 BOA.Y.PRK.AZJ., 2/ 49, 29 Zilhicce 1295/ 24 Aralık 1878; BOA.,Y.PRK.HR.., 6/4, $30 \mathrm{M}$ 1299/ 22Aral1k 1881.

84 Dadyan, a.g.e., s. 274-275; BOA., I.DH., 60996, 22 Cemaziyelevvel 1294/ 24 May1s 1878; Odyan Efendi kendisine yönelik suçlamalara cevap vermiş, iddiaların asılsız olduğunu ve Midhat Paşa ile ilişkisinin daha evvel sona erdiğini ifade etmektedir, bkz. BOA., HR. TO., 525/ 101, ; Odyan Efendi'nin Avrupa kamuoyunu Osmanlı aleyhinde yönlendirmeye çalıştı̆̆ı, bkz. BOA.Y.PRK.AZJ., 2/ 49; Georgeon ise Midhat Paşa'nın gizli bir görevle Odyan Efendi'yi Kanuni Esasi'ye destek olmaları için Paris ve Londra'ya göndedirğini, ancak bu isteğin ilgili ülkeler tarafindan kibarca geri çevrildiğini söyler, bkz. François Georgeon, Sultan Abdülhamid, Çev. Ali Berktay, Homer Kitabevi, İstanbul 2006, s. 75-76. 
resmi taleplerle Esad Paşa, hakkındaki iddialar sebebiyle Odyan Efendi'ye ülkeye dönmesi gerektiğini bildirmiştir. Herhangi bir ihaneti olmadığını ve suçsuz olduğunu ifade eden ve durumundan endişe eden Odyan Efendi İstanbul'a dönmeye yanaşmamış, buna parasızlığını bahane etmiştir. Sefaretin talebiyle devlet yönetiminden para gönderilmesine rağmen Odyan Efendi İstanbul'a gitmeyerek ömrünü Paris'te sefalet içinde tamamlamıştır. ${ }^{85}$ Paris'te yaşadığı dönemde adeta göz hapsinde tutulduğu söylenmektedir. Daha sonrasında da yine Esad Paşa'nın talepleriyle maddi sıkıntı içinde olan Odyan Efendi'ye devlet nakdi yardımda bulunarak vefa göstermiştir. ${ }^{86}$

Sağlık sorunlarına rağmen Paris’teki görevini sürdürmeye çalışan Esad Paşa'ya Fransa Devleti 1883 yılı başlarında birinci dereceden Lejyon Donör nişanı vermiştir. ${ }^{87}$ Esad Paşa kronik rahatsızlıkları dolayısıyla 1883 yılı Ağustos ayında tedavi için üç hafta izin alarak Fransa'daki Royat kaplıcalarına gitmiştir. ${ }^{88} 1885$ sonbaharında Küçük Said Paşa kabinesinin düşmesiyle Dahiliye Nazırı İbrahim Edhem Paşa'nın Paris sefirliğine tayini söz konusu olunca Esad Paşa'yı da Berlin sefirliğine tayin etmek istemişlerdir. ${ }^{89}$ Hatta bu hususta karar alınmasına rağmen Edhem Paşa'nın affını istemesiyle Esad Paşa yerinde kalmıştır. ${ }^{90}$ Zaten Esad Paşa'nın da Berlin'e gitmeye sıcak bakmadığı görülmektedir. ${ }^{91} 1878$ Berlin Kongresi'ne bağlı olarak yaşanan Yunan hududu meselesi, diş politikada gündemi meşgul eden siyasi konulardan biridir. Osmanlı İmparatorluğu'na karşı büyük ülkelerin kendisini destekleyeceğine inanan Yunan Hükümeti Babıâli'ye verdiği notalarla bir an evvel müzakerelere başlanılmasını istemiştir ${ }^{92}$. Bu hususa dair zaman içinde ilki Preveze'de olmak üzere İstanbul, Berlin ve yine İstanbul'da çeşitli konferanslar tertiplenmiştiri" ${ }^{93}$. Sınır meselesinde diğer büyük ülkelerle birlikte Fransa'nın da desteğine ihtyaç duyan Babıâli, Paris Sefiri Esad Paşa aracılığıyla hudut meselesine dair Fransız basınına yansıyan haberleri takip etmiştir. ${ }^{94}$

Esad Paşa bunların dışında sömürgecilik çeçevesinde Tunus'un Fransızlar ve

85 BOA., Y.A.HUS., 166/57, 18 Safer 1298/ 20 Ocak 1881.

86 BOA., Y.EE., 78/55, 13 Rebiülahir 1303/ 19 Ocak 1886.

87 Esad Paşa maiyetinde çalışan Başkâtip Misak Efendi'ye de üçüncü dereceden aynı nişan verilmiştir, bkz. BOA., I.HR., 18075, 13 Rebiülahir 1300/ 21Şubat 1883; Bu nişan, 19 May1s 1802'de Napolyon Bonapart tarafından ihdas olunmuştur, bkz. Sâlnâme-i Nezâret-i Hâriciye, I, s. 388

88 BOA., I.HR., 18270, 6 Şevval 1300/10 Ağustos 1883.

89 BOA., I.DH., 76082, 14 Zilhicce 1302/ 24 Eylül 1885.

90 BOA., Y.A.HUS., 183/57, 20 Zilhicce 1302/ 30 Eylül 1885.

91 BOA., Y.A. HUS., 183/67, 21 Zilhicce 1302/1 Ekim 1885.

92 Bülent Akyay, Teselya Meselesi (1881), Ege Üniversitesi Sosyal Bilimler Enstitüsü Basılmamış Yüksek Lisans Tezi, İzmir 2001, s. 114.

93 Ali Fuat Türkgeldi, Mesâil-i Mühimme-i Siyâsiyye, Yay. haz. Bekir S1tk1 Baykal, II, TTK Basımevi, Ankara 1987, s. 168- 191.

94 Ancak belgede bir içerik yok, bkz. BOA., Y.PRK.TFŞ., 1/34, 07 Rebiülevvel 1298/ 7 Şubat 1881 . 
Mısır'ın İngilizler tarafından işgaliyle yaşanan gelişmelerle de meşgul olmuştur. II. Abdülhamid'in İslam birliği siyaseti kapsamında sürdürülen diplomatik faaliyetlerle bu meselelere dair gelişmeler takip edilmeye çalışılmıştır. $\mathrm{Bu}$ düşünceye gönülden bağlı bir diplomat olarak Esad Paşa sağlık sorunlarına rağmen imparatorluğun bölgedeki hukukunun korunması için çaba sarf etmiştir. ${ }^{95}$ Tunus meselesinde Fransız işgalinin önüne geçmek için Babâli diplomatik girişimlerde bulunmuş, işgali protesto etmiş, ancak içinde bulunduğu siyasi, askeri ve mali sıkıntılar münasebetiyle Fransa ile Tunus arasında imzalanan Bardo Antlaşmasını kabul etmek zorunda kalmıştır. Bu anlaşmaya rağmen II. Abdülhamid, imparatorluğun imaj ve itibarını koruma adına diplomatik yollarla buradaki çıkarlarını sürdürmeye çalışmıştır. ${ }^{96}$ Öte yandan, bu dönemde Mısır sorununun da daha yoğun bir diplomasi trafiği göze çarpmaktadır. II. Abdülhamid Mısır'1 tamamen İngilizlerin eline bırakmamak için büyük çaba sarf etmiş ve bölgedeki çıkarlarına vurgu yaparak Fransızların işgale karşı tavır takınması için uğraşmıştır. ${ }^{97} \mathrm{Bu}$ süreçte Esad Paşa Fransız yetkililerle muhtelif görüşmeler yapmıştır.

1884'te II. Abdülhamid Misır sorununun çözümü için İngilizlere bir teklif sunmuştur. II.Abdülhamid'in de telkinleriyle hükümet tarafindan Adliye Nazırı Hasan Fehmi Paşa bu teklif paralelinde Mısır meselesine dair görüşmeler yapmak üzere 1884 yılı sonlarında yurtdışına görevlendirilmiştir. Bu doğrultuda 15 Ocak 1885'te Berlin'den Paris'e geçtiğinde kendisine Esad Paşa eşlik etmiştir. Esad Paşa Hasan Fehmi Paşa'nın Fransız Başbakanı ve Dışişleri Bakanı ile görüşmesini sağlamıştır. Ancak Fransızlardan gerekli desteği alamamıştır. ${ }^{98}$ İmparatorluğun Mısır'daki haklarından vazgeçmeyen II. Abdülhamid diplomatik girişimlerini 1srarla sürdürmüştür. Bu doğrultuda 1886'da Esad Paşa, Fransız Dışişleri Bakanı Jules Ferry ile yaptığı görüşmede Mısır sorunu ele alınmış ve görüşmenin neticesinde Fransız Hükümeti sorunun çözümünde Babıâli’ye yardımcı olacaklarını ifade etmiştir. ${ }^{99}$ Fransızların, 1887'de Osmanlı İmparatorluğu ile İngilizler arasında imza edilen antlaşmanın tasdikiyle Osmanlı yönetiminin hem kendi hükümranlıklarını hem de Fransa'nın menfaatlerini zedeleyeceği endişesiyle antlaşmayı hiçbir surette kabul etmeyeceklerini Paris sefiri vasıtasıyla

95 Tunus meselesi hakkında Esad Paşa'ya gönderilmesi icap eden telgrafın müsveddesine dair, bkz. BOA., Y.A.RES., 15/19, 5 Cemaziyelevvel 1299/ 25 Mart 1882.

96 BOA., Y.A.HUS., 169/143, 6 Cemaziyelevvel 1299/ 26 Mart 1882: BOA., Y.A. HUS., 169/147, 10 Cemaziyelevvel 1299/ 30 Mart 1882; Hatta Hayreddin Paşa'nın Tunus'a vali tayin edilmesi bile konuşulmuş, ancak artık bunu için vakit çok geçtir, bkz BOA., Y.EE., 75/3, 15 Cemaziyelevvel 1299/ 4 Nisan 1882; Numan Hazar, "Sultan II. Abdülhamid Dönemi Osmanlı Devleti ve Afrika Siyaseti”, Devr-i Hamid, IV (2011), Haz. Metin Hülagu- Şakir Batmaz - Gülbadi Alan, Erciyes Üniversitesi Yayınları, Kayseri, s. 192.

97 Sultan II. Abdülhamid, Siyasi Hatıratım, Dergah Yay. İstanbul 2010, s. 95-96.

98 Süleyman Kızıltoprak, Mısır'da İngiliz İşgali, Osmnalı'nın Diplomasi Savaşı (1882- 1887), Tarih VakfiYurt Yay., İstanbul 2010, s. 142.

99 BOA., Y.PRK.EŞA., 5/27, 24 Şaban 1303/ 28 Mayıs 1886. 
Babıâli'ye iletmiştir. ${ }^{100}$ Nitekim II.Abdülhamid müzakerelere rağmen Fransız ve Rus baskısı neticesinde antlaşmayı onaylamamıştır. ${ }^{101}$

$1887^{\prime}$ de Misır meselesine ilişkin mukaveleden dolay1 yoğun diplomatik müzakereler olmuş ve zaman zaman tansiyon yükselmiştir. Bu gerilime bağlı olarak bazı İngiliz yetkililer yöntem ve tavırlarından şikayet ederek, Rüstem Paşa'nın Londra sefirliğinden alınmasını, yerine Esad Paşa'nın tayin edilmesini istemişlerdir. ${ }^{102}$ Her daim Osmanlı diplomasisine müdahil olmaya çalışan İngilizlerin bu talebi, konuşulsa da, atama gerçekleşmemiş ve Rüstem Paşa 1896'da ölümüne değin görevini sürdürmüştür. Paris Sefiri Esad Paşa'nın sefirliği sırasında gündem teşkil eden konulardan bir diğeri de, Osmanlı borçlarının tasfiyesi hususudur. 1881'de Muharrem Kararnamesi'nin hazırlıkları yürütülürken Avrupalı alacaklılar için ilgili ülkelerde delegeler tayin edilmiştir. Esad Paşa, Fransız alacaklıların da Mösyö J. Valfrey'i tayin ettiklerini ve borçlar hakkında kendisiyle birkaç kez görüştügünü ifade etmiştir. ${ }^{103}$

Daha evvel de dile getirdiğimiz gibi mesleki yaşamı sırasında kendi devlet yönetiminden ve çeşitli ülkelerden aldığı nişanlarla sıkça taltif gören Esad Paşa'ya 1886'da Karadağ Prensi I. Nikola'nın Paris seyahati münasebetiyle Karadağ Prensiliği'nden Danilo nişanı verilmiştir. ${ }^{104}$ Aynı yıl padişahtan Murassa Osmani nişanı almıştır. ${ }^{105}$ Paşaya 1889 'da ise Murassa Mecidi nişanı,1890'da Imtiyaz nişanı altın ve gümüş madalyası ihsan buyrulmuştur. ${ }^{106}$ Mesleki yaşamının sonlarına doğru paşaya bu defa, güzel hizmetlerinden ve meseleleri ele alırken gösterdiği hassasiyetten ötürü Murassa Iftihar nişanı takdim edilmiştir. ${ }^{107}$ Esad Paşa, aldığ bu nişan ve rütbelerle kariyerini taçlandırmıştır.

100 Padişahın mukaveleyi onaylamasına o güne değin hoşgörüyle baklıdığını, ancak bunun İngiliz işgalini meşrulaştırmasıyla Akdeniz'deki dengeleri bozacağı ve bunun da ilgili devletlerin veya Fransa'nın çıkarlarına zarar vereceği belirtilmiştir. Ayrıca Osmanlı Devleti'nin mülkiyet haklarını tehlikeye sokacağı, mukavelenin vahim olayalara sebebiyet vereceği ve sonucunda Osmanlı için pek ağır olacağı dile getirilmiştir, bkz. BOA., Y.PRK.TKM., 10/55, 23 Ramazan 1304/ 15 Haziran 1887.

101 Kiziltoprak, a.g.e., s. 230.

102 ...her vechile mazhar-1 teveccühe ve i'timâd-1 şâhâneleri olan ba'zı İngiliz mu'teberânı Rüstem Paşa hazretlerinin meslek ve etvârından şikâyet eylemekde...... ikinci bir mukâvelenin akdine İngilterece? meyl var ise de bunun husûlü Rüstem Paşa'nın oradan kaldırılmasına.... Müşârün-ileyhin azliyle Londra Sefâretine Paris Sefiri Esad Paşa hazretlerinin ta'yini... , bkz . BOA., Y.A.HUS., 206/22, 05 Zilhicce 1304/ 26 Temmuz 1887; BOA., Y.PRK.BŞK., 11/81, 04 Zilhicce 1304/ 25 Temmuz 1887

103 BOA., Y.PRK.EŞA., 2/66, 25 Ramazan 1298/ 21 Ağustos 1881; Haydar Kazgan, "Düyun-1 Umumiye", Tanzimat 'tan Cumhuriyete Türkiye Ansiklopedisi, III (1985), İletişim Yay., s. 704.

104 BOA., I.HR., 19121, 27 Şaban 1303/ 31 Mayıs 1886; Karadağ'ın bağımsızlı̆̆ı dolayısıyla ihdas edilmiş bir nişandır, bkz. Sâlnâme-i Nezâret-i Hâriciye, I, s.390.

105 BOA., I.DH., 78797, 2 Zilkade 1303/ 2 Ağustos 1886.

106 BOA., I.DH., 88858, 14 Şevval 1306/ 13 Hziran 1889; BOA., DH.SAIDd., 1/604.

107 BOA., I.TAL., 1311/ Ca-022, 02 Cemaziyelevvel 1311/ 11 Kasım1893. 
1888 'de Fransa ile bir piyes yüzünden gerilim yaşanmıştır. Fransız yazar Bornier Hz Muhammed'i hakaretamiz ifadelerle anlatan bir oyun yazmış ve Comédie Française tiyatrosu ile anlaşarak sahnelemek istemiştir. II. Abdülhamid meseleyi bizzat yabancı basın vasıtasıyla öğrenerek Paris Sefiri Esad Paşa'nın bilgilendirilip bu hususta gereğini yapmasını istemiştir. ${ }^{108}$ Akabinde başlatılan diplomatik girişimler neticesinde Fransız yönetiminin dikkati çekilmiş, böyle bir oyuna izin verilmesinin Müslümanlara büyük bir hakaret olacağ1 ve oynanması durumunda Fransız hükümetinin protesto edileceği belirtilerek baskı yapılmıştır. ${ }^{109}$ Diplomatik girişimler ve baskılar neticesinde oynunun sahnelenmesine engel olunmuştur. Hatta bu hususta Fransa'nın İstanbul Elçisi Montebella'ya konunun hassasiyeti iletilmiş ve o da kendi hükümet yetkililerine bunu iletmiştir. Bir müddet gündemi meşgul eden bu problem 1890 yılında çözülmüş Fransız Sefir Montebella hükümetlerinin kararını bizzat kendi gönderidği mektupla Babıâli'ye bildirmiştir. Esad Paşa da bu konuda çaba sarf eden Fransız Cumhurbaşkanı Carnot'ya teşekkür babından bir nişan verilmesini önermiştir. Nişan hususunda görüş ayrılıkları olsa da nihayetinde Esad Paşa Fransız cumhurbaşkanı ile yaptığı görüşmede teşşekür kabilinden bir nişanı kendisine takdim etmiştir. ${ }^{110}$

Esad Paşa'nın Paris sefirliği sırasında yaşanan önemli hadiselerden birisi de 1789 Fransız Devrimi’nin yüzüncü y1ldönümü etkinlikleriyle ilgilidir. Devletin prestijini korumaya azami hassasiyet gösteren Esad Paşa 1889 yılında Fransız Devrimi'nin yüzüncü yılı kutlamaları parelelinde Paris Sergisi'nin açılışına büyük ülke sefirlerinin o esnada Paris'te bulunmayarak katılmayacaklarını Babıâli’ye bildiren bir telgraf çekmiştir. Bu şartlar dahilinde büyük ülke sefirlerinden sadece Osmanlı sefiri bu sergiye iştirak edecektir. Kendi idari ve siyasi yapısı münasebetiyle Babıâli, sefirinin bu etkinlikten uzak durması gerektiğini bildiren bir cevap yazısını Esad Paşa'ya göndererek, sefirini o müşkül durumdan kurtarmiştır. ${ }^{11}$

1893 yazında Esad Paşa hem sağlık koşulları hem de bazı işleri münasebetiyle tekrar İstanbul'a gelmiştir. ${ }^{12}$ Sağlık durumu iyi olmayan Esad Paşa'nın İstanbul'a gelişiyle birlikte Salih Münir Bey'in Paris'e atanması gündeme gelmiştir. ${ }^{113}$ An-

108 Gönderilen telgrafta Bornier'in "Muhammed" ismiyle bir eser sahnelemek istediği ve bununda İslam aleyhinde olduğu ifade edilerek yasaklanması için gereğinin yapılmasını belirtmiştir, bkz. Ahmet Uçar, Sultan, Güç ve Hassasiyet, Çamlıca Basım Yay., İstanbul 2012, s. 173-174.

109 BOA., Y.PRK.TKM., 16/10, 21 Safer 1307/ 17 Ekim 1889.

110 Uçar, Sultan, Güç., s. 185-188.

111 Selim Deringil, İktidarın Sembolleri ve İdeoloji II Abdülhamid Dönemi (1876-1909), Çev. Gül Çağalı Güven, YKY, İstanbul 2002, s. 161-162.

112 BOA., I.HUS., 1311/ M-053, 19 Muharrem 1311/2 Ağustos 1893; BOA., BEO., 18746, 20 Muharrem 1311/ 3 Ağustos 1893.

113 İstirahate ihtiyacı olan Esad Paşa'nın yerine Münir Bey'in tayin edileceğine dair yazılan bir yazı, bkz. BOA., Y.PRK.TKM., 29/69, 05 Safer 1311/ 18 Ağustos 1893. 
cak bu atama olmamış ve Esad Paşa yıl sonuna doğru görev yerine tekrar dönmüştür. ${ }^{114}$ Paris'te uzun yıllar kalan Esad Paşa sıhhatinin iyice bozulmasiyla birlikte hekim kontrolünün ardından, Paris'te kalmasının hayati açıdan tehlikeli olacağ 1 belirtilince müsaade isteyerek 1894 baharında İstanbul'a dönmüştür. ${ }^{115}$ Görevine dönemeyecek olursa, biri tayin edilene kadar, Madrid Sefiri Turhan Bey'in bu görevi yürüteceği bildirilmiştir. ${ }^{116}$ Nitekim görev yerine dönemeyeceğini hissedince vazifesinden ayrılmış ve hazinece kendisine 15000 kuruş mazuliyet maaşı bağlanmıştır. ${ }^{117}$ Şahsiyeti itibariyle Paris'te iyi intiba bıraktığı söylenir. Halefi Yusuf Ziya Paşa ${ }^{118}$ ile kabulünde görüşen Fransız Cumhurbaşkanı Fallieres, selefi Esad Paşa'yı överek kendisine de tüm kapıların açık olacağını ifade etmiştir. ${ }^{119}$ Yılları sefaretlerde ve hariciyede geçen Esad Paşa Fransızcaya olan hakimiyeti dışında Arapça, Farsça ve Almancaya da aşina olduğu belirtilmektedir. Bu yönüyle imparatorluğun beklentilerini karşılayan bir diplomat örneğidir.

Emirgan'daki yalısında istirahate çekilen Esad Paşa'nın rahatsızlığ 1895 yılı başlarında iyice artmış ve 1895 yılı nisan ayı ortalarında yaşamını yitirmiştir. ${ }^{120}$ Perşembe günü devlet erkânından birçok bürokratın da katılımıyla Ayasofya Camii'nde öğle namazını müteakip kılınan cenaze namazının ardından Sultan II. Mahmud'un türbesinin bulunduğu alana naaşı defnedilmiştir. ${ }^{121}$

114 BOA., Y.A.HUS., 284/75, 11 Cemaziyelevvel 1311/ 20 Kasim 1893.

115 BOA, BEO., 28594, 03 Şevval 1311/9 Nisan 1894; BOA., I.HUS., 1311/ L-06, 03 Şevval 1311/9 Nisan 1894

116 BOA, BEO., 28594; BOA., I.HUS., 1311/ L-06

117 BOA., BEO., 38154, 4 Cemaziyelevvel 1312/3 Kasim 1894; BOA., I.ML., 1312/ R-10, 4 Rebiülahir 1312/ 5 Ekim 1894.

118 BOA., I.HUS., 1312/ Ra-042, 13 Rebiülevvel 1312/14 Eylül 1895; Meclis-i Maliye Reisi Yanyalızade Mehmed Şakir Bey’in oğlu olan Yusuf Ziya Paşa, Belgrad, Roma, Viyana, Paris ve Vaşington olmak üzere beş farklı yerde elçilik görevinde bulunan tek diplomattır. Diplomatlığının yanı sıra sanatçı kişiliği ile de ün yapmıştır, bkz. Pakalın, Sicill-i Osmanî Zeyli, XIX, Yay. haz. M. Metin Hülagu, TTK, Ankara 2009, s. 54-56; Kuneralp, “Tanzimat Sonrası”, s. 126.

119 Kuneralp, "Tanzimat Sonrası", s.118; BOA., BEO., 37130, 15 Rebiülahir 1312/ 16 Ekim 1894.

120 The Levant Herald, 16 April 1895.

121 Girit Eski Valisi Turhan Paşa, Hariciye Müsteşarı Nuri Bey, Babıâli Birinci Tercümanı Davud Efendi, Petersburg Sefareti Müsteşarı Ali Ferruh Bey gibi önemli bürokratlar cenazeye iştirak etmişir, bkz. The Levant Herald, 16 April 1895. 


\section{Sonuç}

1830'larda sürekli diplomasinin yeniden işlemeye başladığ 1 bir dönemde ilmiye sınıfina mensup bir ailenin ferdi olarak dünyaya gelmiş olan Esad Paşa imparatorluğun modern yüzüne geleneksel dokular da eklemiş dikkate değer bir şahsiyettir. Diplomasi mesleğine paralel ancak klasik dönemden kalan Divan-1 Hümayun Kalemi'nde çıraklığa başlamıştır. Akabinde bu klasik birimden ayrilarak, reform döneminin önemli kalemlerden biri olan Tercüme Odası'nda gelişimini sürdürmüş ve daha sonra Batı'da aldığı eğitimle bu süreci taçlandımıştır. Aldığı e ğitim, dil kabiliyeti ve diğer özelliklerle birlikte Esad Paşa imparatorlukta çekirdekten yetişmiş diplomatların ilk örneğidir. Bunlarla birlikte değerlendirildiğinde Osmanlı İmparatorluğu'nun son döneminde elçilik yapan birçok kişiyle mukayese edildiğinde Osmanlı diplomasisinin istikrarlı ve takdir gören diplomatlarından biri olduğu söylenebilir. Zira birçok diplomatın bir veya iki kez görev aldığı bir ortamda, Esad Paşa Atina, Roma, Viyana, Madrid ile Paris gibi Avrupa başkentlerinde sefirlik yapmış, Berlin ve Londra sefirlikleri içinde adı geçmiştir. Esad Paşa, kırk yılı yakın bir süreyi hariciyenin iç ve dış ofislerinde çalışarak geçirmiş ender devlet adamlarından biridir.

Esad Paşa sağlık sorunlarına rağmen itimat edilen bir sefir olması münasebetiyle de mesleki görevini başarıyla ve sabırla sürdürmüştür. Zaman zaman siyasi çekişmelerin ve çatışmaların sonucu olarak karşılaştığı olumsuzluklara pek aldırış etmeden kendisine tevdi edilen vazifeleri yerine getirmeye gayret ederek örnek bir devlet adamı profili çizmiştir. Devlet menfaatlerini ön plana koyarak, meselelerin çözüm yollarında sabırlı ve rasyonel davranabilen bir diplomat görüntüsü vermiştir. Öte yandan Esad Paşa sefirlikleri sırasında Avrupa'daki güç dengesine dair Babıâli'ye aktardığı bilgilerle de iyi bir gözlemci ve analist olduğu söylenebilir. 


\section{Kaynakça}

\section{Arşiv Kaynakları}

Babıâli Evrak Odası (BEO): 18746, 28594, 37130, 38154.

Cevdet Hariciye (C.HR.): 1716, 7511.

Dâhiliye Nezareti Sicil-i Ahval Defteri( DH. SAIDd.): 1/604, 2/1006, 26/435.

Hatt-ı Hümayun Tasnifi (HAT): 9801, 10689, 12332, 53571, 54103.

Hariciye Nezareti Mektubî Kalemi (HR. MKT.): 12/10, 234/69, 259/95, $302 / 14,315 / 89$.

Hariciye Nezareti Siyasi (HR.SYS): 176/40, 23 Ocak 1878.

Hariciye Nezareti Tercüme Odasl ( HR. TO.): 131/85, 311/13, 525/ 101.

Iradeler- Dâhiliye (İ.DH.): 4862, 8582, 9411 , 30924, 33759, 37672, 60996, 61639, 66266, 66400, 76082, 78797, 88858.

Iradeler-Girit (I.MTZ.GR.): 432.

Iradeler- Hariciye Nezareti (I.HR.): 1685, 4180, 6900, 7768, 9741, 10588, 10854, 13797, 14190, 14247, 15324, 15355, 15515, 15651, 15670-1, 15675, $15778,15869,16300,16303,16629,16687,17084,17150,17157,17479,17690$, $17708,18075,18270,19121,21531,21549$,

İradeler-Husûsî (I.HUS.): 1311/ M-053, 1311/ L-06, 1312/ Ra-042.

Iradeler-Maliye (I.ML.): 1312/ R-10.

Iradeler-Meclis-i Vâlâ (I.MVL.): 3298.

İradeler-Taltîfât (İ.TAL.): 1311/ Ca-022.

Iradeler-Yunanistan (I.MTZ (01)): 499.

Maarif Nezareti Mektubi Kalemi (MF.MKT.): 97/18.

Sadaret Amedi Kalemi Belgeleri (A.AMD.): 77/22.

Sadaret Divan Kalemi (A.DVN.): 15/47

Sadaret Mühimme Kalemi Evrakı (A.MKT. MHM.): 454/55,

Şehbenderlik Defteri (A.DVNS. ŞHB.d): 1.

Yıldız Esas Evrakı (Y.EE.): 75/3, 78/55.

Yıldız Perakende Evrakı Arzuhâller ve Jurnaller (Y.PRK. AZJ.): 2/ 49.

Yıldız Perakende Evrakı Elçilik, Şehbenderlik ve Ateşemiliterlik (Y.PRK. EŞA.) : 2/66, 5/27.

Yıldız Perakende Evrakı Hariciye Nezareti Maruzatı (Y.PRK. HR):6/4. 
Yıldız Perakende Evrakı Mabeyn Başkitabeti (Y.PRK. BŞK.): 11/81.

Yıldız Perakende Evrakı Tahrirat-ı Ecnebiye ve Mabeyn Mütercimliği (Y.PRK. TKM).: 10/55, 16/10, 29/69.

Ylldı Sadaret Hususi Maruzat Evrakı (Y.A.HUS.): 160/62, 163/67, 166/57, 169/143, 169/147, 183/57, 183/67, 206/22, 284/75.

Yıldız Sadaret Resmî Maruzat Evrakı (Y.A.RES): 15/19.

Yıldız Teşrifat-ı Umumiye Dâiresi (Y.PRK. TŞF.): 1/34.

\section{Salnameler}

Salname-i Devlet-i Aliyye 1266, 1274, 1286.

\section{Gazeteler}

The Levant Herald, 12 January 1881.

The Levand Herald, 16 April 1895.

\section{Araştırma Eserleri}

Akyay, Bülent, "Teselya Meselesi (1881)", (Yayımlanmamış Yüksek Lisans Tezi), Ege Üniversitesi Sosyal Bilimler Enstitüsü, İzmir, 2001.

Akyıldız, Ali, Tanzimat Dönemi Osmanlı Merkez Teşkilatında Reform (18361856), İstanbul, Eren Yayınları, 1993.

Armaoğlu, Fahir, 19. Yüzyıl Siyasi Tarihi (1789- 1914), Ankara, TTK, 1997.

Bilim, Cahit, Tanzimat Devrinde Türk Eğitiminde Çağdaşlaşma (1836-1876), Eskişehir, Anadolu Üniversitesi Yayınları, 1984. , "Babıâli Tercüme Odası", Ankara, OTAM, I, 1990.

Candemir, Aykan -Seropyan, Vağarşağ, "Abroyan Sahak”, Yaşamları ve Yapıtlarılla Osmanlılar Ansiklopedisi, I, İstanbul, YKY, 2008.

Dadyan, Saro, Osmanlı'da Ermeni Aristokrasisi, İstanbul, Everest Yayınları, 2011.

Davison, Roderic H., "Vienna As a Major Diplomatic Post In The Nineteenth Century", ed. Andreas Tietze, Habsburgisch-Osmanische Beziehungen/ Relations Habsbourg- Ottomanes, Vienna, 1985.

Deringil, Selim, Iktidarın Sembolleri ve İdeoloji II. Abdülhamid Dönemi (1876-1909), çev. Gül Çağalı Güven, İstanbul, YKY Yayınları, 2002.

Erdoğdu, Teyfur, "1856- Paris Kongresi-1878 Berlin Kongresi Arasında Osmanlı Dış Politikası”, Çağdaş Türk Diplomasisi: 200 Yıllık Süreç- Ankara 15-17 Ekim Kongreye Sunulan Bildiriler, Ankara, TTK, 1999.

Ergin, Osman Nuri, Türk Maarif Tarihi, İstanbul, Eser Neşriyat, 1977. 
Gövsa, İbrahim Alaeddin, Meşhur Adamlar: Hayatları ve Eserleri, İstanbul, Sedat Simavi, 1949.

Hazar, Numan, "Sultan II. Abdülhamid Dönemi Osmanlı Devleti ve Afrika Siyaseti”, Devr-i Hamid, IV, haz. Metin Hülagu, Şakir Batmaz, Gülbadi Alan, Kayseri, Erciyes Üniversitesi Yayınları, 2011.

Kazgan, Haydar, "Düyun-1 Umumiye”, Tanzimat'tan Cumhuriyete Türkiye Ansiklopedisi, III, İletişim Yayınları, 1985.

Kızıltoprak, Süleyman, Mısır'da İngiliz İşgali, Osmanlı'nın Diplomasi Savaşı (1882-1887), İstanbul, Tarih Vakfi Yurt Yayınları, 2010.

Korkut, Hasan, Osmanlı Elçileri Gözüyle Avrupa, İstanbul, Gökkubbe Yayınları, 2007.

Kuran, Ercümend, Avrupa'da Osmanlı İkamet Elçiliklerinin Kuruluşu ve İlk Elçilerin Siyasi Faaliyetleri 1793-1821, Ankara, TKAE, 1988.

, "1793-1811 Döneminde İlk Osmanlı Mukim Elçilerinin Diplomatik Faaliyetleri”, Çağdaş Türk Diplomasisi:200 Yıllık Süreç-Ankara 1517 Ekim Kongreye Sunulan Bildiriler, Ankara, TTK, 1999.

, "Ali Efendi (Seyyid, Moralı)", Yaşamları ve Yapıtlarıyla Osmanlılar Ansiklopedisi, I, İstanbul, YKY, 2008.

Kuneralp, Sinan, İspanya'da Osmanlı Temsilciliği ve Osmanl1-İspanyol Müsabetleri (1857-1922), Türk Kültürü Araştırmaları Dergisi, X-XIV/ 1-2, Ankara, 1973-1975.

, "Tanzimat Sonrası Osmanlı Sefirleri”, Çă̆daş Türk Diplomasisi:200 Yıllık Süreç- Ankara 15-17 Ekim Kongreye Sunulan Bildiriler, Ankara, TTK, 1999.

, Son Dönem Osmanlı Erkânı ve Ricali (1839-1922) Prosopografik Rehber, İstanbul, İsis Press, 1999.

Malhasyan Silvart Kayar, "Krikor Odyan", Yaşamları ve Yapıtlarıyla Osmanlılar Ansiklopedisi, II, İstanbul, YKY, 2008.

Mehmed Süreyya, Sicill-i Osmanî, II, haz. Nuri Akbayar, İstanbul, Tarih Vakf1 Yurt Yayınları, 1999.

Okay, M. Orhan, "Aziz Ali Efendi”, Yaşamları ve Yapıtlarıyla Osmanlılar Ansiklopedisi, I, İstanbul, YKY, 2008.

Özcan, Abdülkadir, "Ahmed Cevad Paşa”, Yaşamları ve Yapıtlarılla Osmanlılar Ansiklopedisi, I, İstanbul, YKY, 2008.

Öztuna, Yılmaz, Tanzimat Paşaları Âli ve Fuâd Paşalar, İstanbul, Ötüken Yayınlar1, 2006. 
Pakalın, Mehmed Zeki, Sicill-i Osmanî Zeyli, VI, haz. Özen Tok- Hava Selçuk, Ankara, TTK, 2008.

TTK, 2008.

Sicill-i Osmanî Zeyli, IX, haz. Ali Aktan, Ankara, Ankara, TTK, 2008.

, Sicill-i Osmanî Zeyli, XIX, haz. M. Metin Hülagu,

Sâlnâme-i Nezâret-i Hâriciye, I-II, haz. Ahmet Nezih Galitekin, İstanbul, İşaret Yayınları, 2003.

Saydam, Abdullah, "Tanzimat Devri Reformları”, Türkler, XII, Ankara, Yeni Türkiye Yayınları, 2002.

Schmiede, Ahmed, Osmanlı ve Prusya Kaynaklarına göre Giritli Ali Aziz Efendi'nin Berlin Sefareti, İstanbul, 1990.

Soysal, İsmail, Fransız İhtilali ve Türk-Fransız Diplomasi Münasebetleri (1789-1802), Ankara, TTK, 1999.

Sultan II. Abdülhamid, Siyasi Hatıratım, 7. bs., İstanbul, Dergah Yayınları, 2010 .

Tuncer, Hüner, Eski ve Yeni Diplomasi, Ankara, Ümit Yayınları, 1995.

Türkgeldi, Ali Fuat, Mesâil-i Mühimme-i Siyâsiyye, haz. B. S1tkı Baykal, II, Ankara, TTK Basımevi, 1987.

Uçar Ahmet, Sultan, Güç ve İktidar, İstanbul, Çamlıca Basım Yayınları, 2012.

Unat, Faik Reşit, Osmanlı Sefir ve Sefaretnameleri, Ankara, TTK, 1987.

Yalçınkaya, M. Alaaddin, “İsmail Ferruh Efendi’nin Londra Büyükelçiliği ve Siyasi Faaliyetleri”, Pax Ottomana Studies In Memoriam Prof. Dr. Nejat Göyünç, ed. Kemal Çiçek, Ankara, Yeni Türkiye Yayınları, 2001.

Osmanlılar Ansiklopedisi, II, İstanbul, YKY, 2008.

, "Yusuf Agah Efendi", Yaşamlarl ve Yapitlarıly , “Sir Robert Ainslie'nin İstanbul Büyükelçiliği (1776-1794)", Osmanlı Araştırmaları, XXXI, İstanbul, 2008. 
